Dokuz Eylül Üniversitesi-Mühendislik Fakültesi

Fen ve Mühendislik Dergisi

Cilt 20, Sayı 58, Ocak, 2018
Dokuz Eylul University-Faculty of Engineering Journal of Science and Engineering Volume 20, Issue 58, January, 2018

DOI: $10.21205 /$ deufmd.2018205823

\title{
Adsorption of Remazol Blue (Rb) onto The Chitosan/SEP Biocomposite From Aqueous Solution
}

\author{
Aylin ALTINIŞIK TAĞAÇ ${ }^{1}$, Mehmet Kadir YURDAKOÇ² \\ 1 Dokuz Eylul University, Science Faculty, Chemistry Department, 35390 Buca, Izmir, \\ Turkey, ORCID: 0000-0002-1813-7238 \\ 2 Dokuz Eylul University, Science Faculty, Chemistry Department, 35390 Buca, Izmir, \\ Turkey, ORCID: 0000-0002-5017-4100
}

(Alınıș / Received: 22.06.2017, Kabul / Accepted: 27.12.2017, Online Yayınlanma / Published Online: 20.01.2018)

Keywords Adsorption, Chitosan, Sepiolite, Biocomposite

\begin{abstract}
In this study, chitosan/sepiolite (CS/SEP) biocomposites were prepared. The effects of molar ratios of CS and SEP, initial $\mathrm{pH}$ and temperature on the adsorption capacities of the biocomposites have been investigated. In order to determine the adsorption capacities of the sorbents, the sorption data were analyzed by using Langmuir and Freundlich equations. Langmuir equation showed higher conformity than Freundlich equation. The adsorption of Remazol Blue which has an anionic structure on biocomposite of chitosan changes with the amounts of sepiolite on the biosorbent. As the ratio of negatively charged sepiolite increases, as expected, the adsorption capacity decreases. The adsorption capacities of biocomposites were determined as 256, 126 and $23 \mathrm{mg} / \mathrm{g}$ at $318 \mathrm{~K}$ for SEP1, SEP2 and SEP5, respectively. The removal of $\mathrm{RB}$ was reached to $99 \%$ at the optimum $\mathrm{pH}$ of 5 . From kinetic experiments, it was observed that the sorption process followed the pseudo-second-order kinetic model. According to thermodynamic calculations, the adsorption nature is determined by the results of enthalpy and activation energy as physical activation. It was found that chitosan biocomposites can be used as adsorbents at relatively low $\mathrm{pH}$ values..
\end{abstract}

\section{SULU ÇÖZELTİDEKİ REMAZOL MAVİSİ (RB) 'nin KİTOSAN / SEP BIYYOKOMPOZİTí ÜZERİNE ADSORPSIYYONU}

Anahtar Kelimeler Özet: Bu çalıșmada, kitosan/sepiyolit (CS/SEP) biyokompozitleri Adsorpsiyon, Kitosan, Sepiyolit, Biyokomposit hazırlanmıștır. SEP mineralinin molar oranlarının farklanmasının, boya çözeltisinin bașlangıç pH değerinin ve sıcaklığın Remazol mavisinin (RB) sulu çözeltiden SEP üzerindeki adsorpsiyonu üzerine olan etkileri incelenmiștir. Adsorpsiyon kapasitesini belirlemek için, adsorpsiyon verileri Langmuir ve Freundlich eşitlikleri kullanılarak analiz edilmiştir. Langmuir eşitliği, Freundlich eşitliğinden daha yüksek uygunluk göstermiştir. Anyonik yapıdaki Remazol mavisinin kitosan biyokompoziti üzerindeki tutunması yapıdaki sepiyolit miktarına göre 
farklanmaktadır. Negatif yüklü sepiyolit minerali oranı arttıkça adsorpsiyon kapasitesi beklendiği gibi azalmaktadır ve adsorpsiyon kapasitesi SEP1, SEP2 ve SEP5 için $318 \mathrm{~K}$ de sırasıyla, 256, 126 ve $23 \mathrm{mg} / \mathrm{g}$ olarak belirlenmiștir. \%99 RB uzaklaştırılmasına optimum değer olan $\mathrm{pH} 5^{\prime}$ te ulaşılmıştır. Kinetik deneylerden, adsorpsiyon sürecinin yalancı-ikincimertebe kinetik modeline uygunluk gösterdiği elde edilmiştir. Termodinamik hesaplamalar sonucunda entalpi ve aktivasyon enerjisi sonuçlarına göre fiziksel adsorpsiyon olduğu belirlenmiştir. Kitosan biyokompozitinin düşük $\mathrm{pH}$ değerlerinde adsorbent olarak kullanılabilir olduğu bulunmuștur.

*Corresponding author: E-mail: aylin.altinisik@deu.edu.tr

\section{INTRODUCTION}

Dyes are widely used in industries such as textiles, leather, rubber, paper, plastic, cosmetics, etc. to color their final products. Wastewater containing even a small amount of dyes can severely affect the aquatic life due to the reduction of light penetration and their toxicity. Many dyes and color effluents are toxic and have carcinogenic and mutagenic effects that influence environment and also human. Therefore, colored wastewater cannot be discharged without adequate treatment. As dyes are designed to resist breakdown with time and exposure to sunlight, water, soap and oxidizing agent, they cannot be easily removed by conventional wastewater treatment processes due to their complex structure and their synthetic origins. Thus, dye removal has been an important but challenging area of wastewater treatment [1].

Dye removal from wastewater effluent is a major environment problem because of the difficulty of treating such streams by conventional physical, chemical, physico-chemical and biological treatment methods. Several studies have been carried out for biological, physical and chemical treatment of dye containing effluents [2, 3]. Among these, biodegradation, adsorption, chlorination and ozonation are the most commonly used conventional methods. Chemical treatment using chlorine or ozone has led to more successful results, but since the required high dosages are not found economically feasible [2]. Among these methods, adsorption has been found to be one of the best popular physico-chemical treatment methods for removing dyes with potential applications.. Activated carbon [4] is normally employed for this purpose; however, Due to its high price it has not been used on a widescale application. Therefore, other inexpensive and effective adsorbents have been tested. A number of references outline the application of adsorbents such as fly-ash [5], kaolinite, bauxite and fuller's earth [6], sepiolite [7], rice husk [8], eucalyptus bark [9], post-vanillin V [10] and chitin [11]. They tested in terms of the effect of adsorbent particle size, $\mathrm{pH}$ effect and process temperature or mixing speed on the process effectiveness. Many authors have reported that dye adsorption onto biological adsorbents occurs through various mechanisms [5,8-11].

Chitosan (CS) is the $N$-deacetylated derivative of chitin and the second most plentiful natural biopolymer. Chitosan has been extensively investigated for several decades for molecular separation, food packaging film, artificial skin, bone substitutes, water engineering and so on, owing to its good mechanical properties, 
biocompatibility, biodegradability, multiple functional groups as well as solubility in aqueous medium [12]. However, its all properties such as thermal stability, hardness and gas barrier properties are not good enough to provide those wide applications. [13].

This biosorbent composed of two constituents, namely Chitosan and Sepiolite. Chitosan also has exhibited a higher capacity for adsorption of colorant than activated carbon. Chitosan contains amine or amide nitrogen in varying proportions [14, 15]. Adsorption can occur by van der Waals attraction, hydrogen bonding and coulombic attraction. The amino ($\mathrm{NH}_{2}$ ) and hydroxyl $(-\mathrm{OH})$ groups on Chitosan chains can serve as coordination and reaction sites. These groups can lead to the adsorbents having a larger adsorption capacity for acid dyes or anionic dyes. In addition, Chitosan is economically attractive, since it can be obtained from the deacetylation of chitin [16].

On the other hand, Sepiolite (SEP) is a hydrous magnesium silicate whose ideal formula is

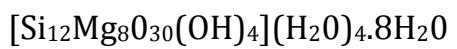

according to the model of BraunerPreisinger [17, 18]. It is used in various applications due its high surface area, porosity, fibrous structure and surface activity. It is also utilized in the production of stable suspensions of high viscosity at low concentrations. These properties provide the basis for a variety of catalytically, sorptive and rheological application $[17,18]$.

Adsorption of a dye from solution is mainly dependent on the dye's properties, structure and to an equal extent on the surface chemistry of the adsorbent.

Polymer/layered silicate composites frequently exhibit remarkably improved mechanical and physicochemical properties and are attracting considerable interest in polymer science field [19].

In this study it was intended to synthesize and characterize the CS/SEP biocomposites. The adsorption kinetics and isotherms for Remazol Blue (RB) dye from water solution onto biocomposite with CS to SEP molar ratio of $\% 2: 1, \% 2: 2$ and $\% 2: 5$ was compared with bare CS. The effects of various experimental conditions, such as different molar ratios of $\mathrm{CS}$ to SEP, initial $\mathrm{pH}$ and temperature was also investigated.

\section{Materials and Methods}

\subsection{Materials}

Chitosan (highly viscous) was obtained from Fluka (degree of deacetylation: $\quad 75-85 \%$, average molecular weight: 5.105-7.105 $\mathrm{g} \mathrm{mol}^{-1}$ ) as a flaked material. Acetic acid (HAc) and sodium hydroxide $(\mathrm{NaOH})$ were purchased from Riedel de Haen. Sepiolite (SEP) was obtained from Eskişehir, Turkey. The chemical composition and X-ray diffraction (XRD) data of the SEP was given in previous publication [20].

\subsection{Preparation of the Biocomposites}

Chitosan /Sepiolite biocomposite was synthesized according to our previous study [7]. Chitosan solution was prepared by dissolving chitosan (CS) in a $2 \%(\mathrm{v} / \mathrm{v})$ aqueous acetic acid solution at a concentration of $2 \mathrm{wt} \%$ followed by filtering to remove the insoluble material. SEP was first swelled by $50 \mathrm{~mL}$ distilled water and then added to $50 \mathrm{~mL}$ chitosan solution with SEP contents of $1 \mathrm{wt} \%, 2 \mathrm{wt} \%$, $5 \mathrm{wt} \%$, followed by stirring at $60^{\circ} \mathrm{C}$ for $6 \mathrm{~h}$. After that, CS/SEP solutions were cast on a Petri dish and dried in vacuum oven at $60^{\circ} \mathrm{C}$ for $48 \mathrm{~h}$. The dry films still contained a small quantity of 
the solvent (HAc), which formed chitosonium acetate. After drying, the films were soaked in $1 \mathrm{M}$ aqueous $\mathrm{NaOH}$ for $5 \mathrm{~h}$ to neutralize the acid followed by rinsing in distilled water to neutral and then dried at vacuum oven at $60^{\circ} \mathrm{C}$ for $24 \mathrm{~h}$. They were termed SEP-X in which $\mathrm{X}$ is the content of SEP percentage.

\subsection{Adsorption from Solution Experiments}

Adsorption isotherms were determined by using batch equilibrium method. For batch adsorption experiments, $0.02 \mathrm{~g}$ of $\mathrm{CS} / \mathrm{SEP}$ was added into $25 \mathrm{~mL}$ of different initial concentrations of RB solution. Concentrations of $\mathrm{RB}$ in aqueous solutions were between 3 and 50 ppm. The solutions were shaken at $100 \mathrm{rpm}$ in a temperature controlled shaking water bath for $24 \mathrm{~h}$. After $24 \mathrm{~h}, \mathrm{CS} / \mathrm{SEP}$ film was taken out and equilibrium concentration of $\mathrm{RB}$ was determined spectrophotometrically by using Shimadzu UV-Visible 1601 Model Spectrophotometer at $602.0 \mathrm{~nm}$.

The amount of RB adsorbed on CS/SEP was calculated by difference of initial and the equilibrium concentrations of RB. The same procedures were performed at solution temperatures of $298 \mathrm{~K}, 308 \mathrm{~K}$ and $318 \mathrm{~K}$ to find thermodynamic parameters. Experiments were also carried out at various time intervals to determine the kinetic parameters.

The influence of $\mathrm{pH}$ on $\mathrm{RB}$ removal was studied by adjusting $\mathrm{pH}$ of the $\mathrm{RB}$ solutions (200 ppm) in the range of 2 12 using a $\mathrm{pH}$ meter (Inolab WTW). The solutions were agitated with 25 $\mathrm{mL}$ of dye solution and $0.02 \mathrm{~g}$ of adsorbent at $25^{\circ} \mathrm{C}$ for $24 \mathrm{~h}$.

\section{Results 3.1 Adsorption Kinetics}

In order to optimize the design of an adsorption system of RB onto SEP1, SEP2 and SEP5, it is important to establish the most appropriate correlations for the equilibrium data for each system. Adsorption kinetics was determined using two different equations which are known as pseudofirst-order (1) and pseudo-secondorder equations (2).

$$
\begin{aligned}
& \log \left(q_{e}-q_{t}\right)=\log q_{e}-k_{1} t / 2.303 \\
& t / q_{t}=1 / k_{2} q_{e}^{2}+t / q_{e}
\end{aligned}
$$

where $q_{t}$ is the amount of RB adsorbed $\left(\mathrm{mg} \mathrm{g}^{-1}\right)$ on chitosan at various time $t$, $q_{e}$ the amount of $\mathrm{RB}$ adsorbed at equilibrium (mg $\mathrm{g}^{-1}$ ) for the pseudo first order adsorption, $k_{1}$ the pseudo first order rate constant for the adsorption process $\left(\mathrm{min}^{-1}\right), q_{e}$ the maximum adsorption capacity ( $\left.\mathrm{mg} \mathrm{g}^{-1}\right)$ for the pseudo second order adsorption, $k_{2}$ the rate constant of pseudo second order for the adsorption ( $\mathrm{g} \mathrm{mg}^{-1} \mathrm{~min}^{-1}$ ). The results were given in Table 1, 2 and Figure 1. The adsorption of RB on SEP1, SEP2 and SEP5 were better described by the pseudo-first-order model rather than by the pseudo-second-order. As it can be seen in Table 1 and 2, correlation coefficients for pseudo-first-order model were greater than those of pseudo-second-order model. Also the adsorption capacity of biocomposites was increased with decreasing with amount of sepiolite due to the anionic character of RB. On the other hand, these kinetic studies were carried out at $298 \mathrm{~K}$ and $308 \mathrm{~K}$. The difference of the temperature positively influenced adsorption capacity and was increased the capacity of adsorption. 

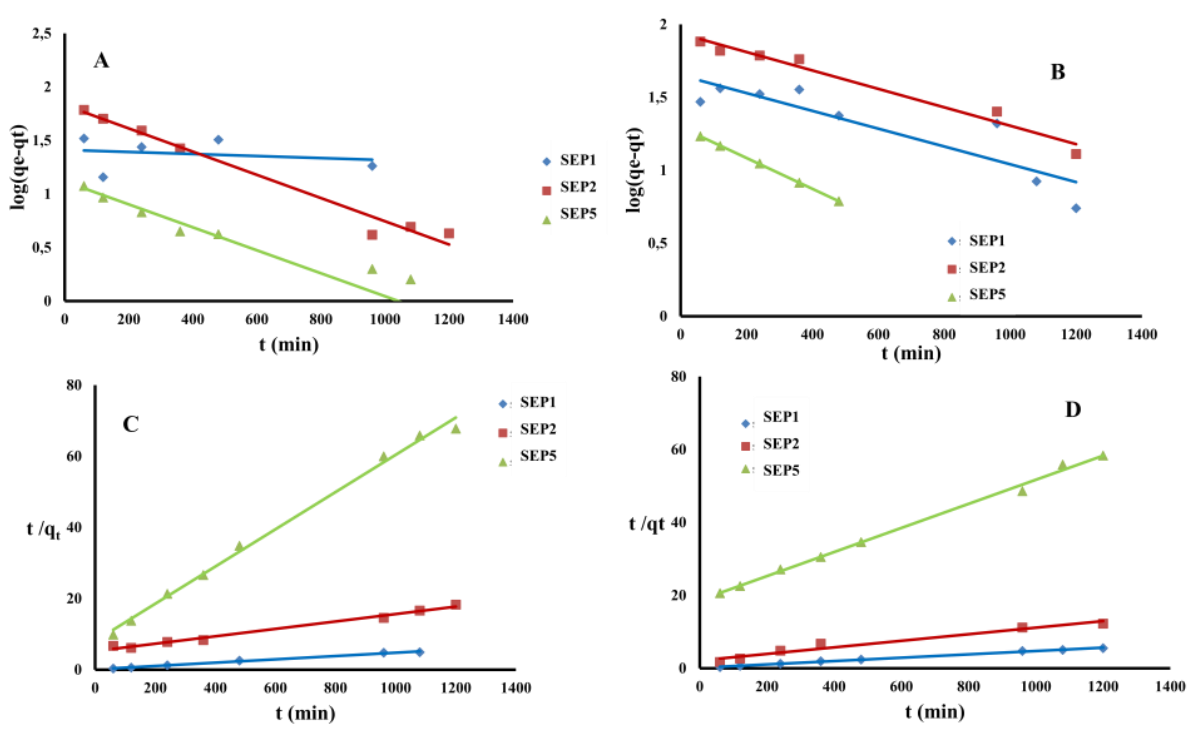

Figure 1. Pseudo-first-order plots for adsorption of RB onto SEP1, SEP2 and SEP5 at 298K (A), 308 K (B); Pseudo-second-order plots for adsorption of RB onto SEP1, SEP2 and SEP5 at 298K (C), $308 \mathrm{~K}(\mathrm{D})$.

Table 1. The pseudo-first-order parameters for RB $\left(200 \mathrm{mg} \mathrm{g}^{-1}\right)$ on SEP1, SEP2 and SEP5 at different temperatures

\begin{tabular}{llll}
\hline 298K & $\mathrm{R}_{1}{ }^{2}$ & $\mathrm{k}_{1}\left(\mathrm{~min}^{-1}\right) \times 10^{+3}$ & $\mathrm{qe}_{\mathrm{e}}\left(\mathrm{mg} \mathrm{g}^{-1}\right)$ \\
\hline SEP1 & 0.05 & 0.2 & 26.0 \\
SEP2 & 0.98 & 3.0 & 67.7 \\
SEP5 & 0.87 & 3.0 & 13.1 \\
\hline 308K & & & \\
\hline SEP1 & 0.63 & 2.3 & 49.3 \\
SEP2 & 0.97 & 1.4 & 86.4 \\
SEP5 & 0.85 & 3.2 & 22.5 \\
\hline
\end{tabular}

Table 2. The pseudo-second-order parameters for RB $\left(200 \mathrm{mg} \mathrm{g}^{-1}\right)$ on SEP1, SEP2 and SEP5 at different temperatures

\begin{tabular}{llll}
\hline 298K & $\mathrm{R}_{2}{ }^{2}$ & $\mathrm{k}_{2}\left(\mathrm{~min}^{-1}\right) \times 10^{+5}$ & $\mathrm{q}_{\mathrm{e}}\left(\mathrm{mg} \mathrm{g}^{-1}\right)$ \\
\hline SEP1 & 0.99 & 26.0 & 212 \\
SEP2 & 0.99 & 2.1 & 96 \\
SEP5 & 0.99 & 3.4 & 19 \\
\hline 308K & & & 222 \\
\hline SEP1 & 0.99 & 12 & 111 \\
SEP2 & 0.96 & 3.8 & 30 \\
SEP5 & 0.99 & 5.9 & \\
\hline
\end{tabular}




\subsection{Adsorption Isotherms}

Adsorption studies were carried out to determine the adsorption isotherms in terms of Langmuir and Freundlich isotherms. Langmuir (3) and Freundlich equations (5) are applied to evaluate the adsorption data.

$\mathrm{Ce}_{\mathrm{e}} / \mathrm{q}_{\mathrm{e}}=1 /\left(\mathrm{q}_{\mathrm{m}} \mathrm{L}\right)+\mathrm{Ce}_{\mathrm{e}} / \mathrm{q}_{\mathrm{m}}$

where $q_{\mathrm{e}}$ is the RB uptake per unit weight of adsorbent per unit weight of adsorbent at equilibrium $\left(\mathrm{mg} \mathrm{g}^{-1}\right)$ and $C_{\mathrm{e}}$ is the equilibrium $\mathrm{RB}$ concentration in aqueous phases (mg L${ }^{-1}$ ). The constant $q_{\mathrm{m}}$ is the monolayer adsorption capacity $\left(\mathrm{mg} \mathrm{g}^{-1}\right)$ and $L$ is related with the energy of the adsorption ( $\mathrm{L} \mathrm{mg}^{-1}$ ). Plots of $C_{\mathrm{e}} / q_{\mathrm{e}}$ versus $C_{\mathrm{e}}$ yield a straight line with slope $1 / q_{\mathrm{m}}$ and intercept $1 / q_{\mathrm{m}} L$.

To determine the adsorption process is favorable or unfavorable, for the Langmuir type adsorption process, the isotherm shape can be classified by a term $R_{L}, a$ dimensionless constant separation factor, which is defined as below;

$\mathrm{R}_{\mathrm{L}}=1 /\left(1+\mathrm{LC}_{0}\right)$

Where $C_{0}$ is initial RB concentrations $\left(\mathrm{mg} \mathrm{L}^{-1}\right)$. The shapes of the isotherms for $0<R_{L}<1, R_{L}>1, R_{L}=1$ and $R_{L}=0$ are favorable, linear and irreversible respectively [21].

The values of $R^{2}, q_{m}, L$ and $R_{L}$ for each biocomposites were given in Table 3 . The adsorption capacity of SEP1 for RB was higher than the mean values of those of SEP2 and SEP5. The monolayer sorption capacities were determined for SEP1 as 196, 250 and $256 \mathrm{mg} \mathrm{g}^{-1}$ at $298 \mathrm{~K}, 308 \mathrm{~K}$ and $318 \mathrm{~K}$, respectively (Table 3 ). As is also understood from the results, the monolayer sorption capacity was increased with temperature. Also, as it can be clearly seen in Table 3 , the monolayer capacity was changed with temperature.

Heterogeneous surface sorption is explained by Freundlich isotherm equation (5);

$\log q_{e}=1 / n \log C_{e}+\log K_{f}$

Where $\mathrm{q}_{\mathrm{e}}$ is the equilibrium of solid phase amount of RB adsorbed per unit weight of the biocomposite ( $\mathrm{mg} \mathrm{g}^{-1}$ ), $\mathrm{Ce}_{\mathrm{e}}$ is the equilibrium RB concentration $\left(\mathrm{mgL}^{-1}\right)$. The values of $\mathrm{n}$ and $\mathrm{K}_{\mathrm{f}}$ were calculated from the slope and intercept of the plot of log $\mathrm{q}_{\mathrm{e}}$ versus $\log \mathrm{C}_{\mathrm{e}}$. The Freundlich constant $\mathrm{K}_{\mathrm{f}}$ indicates the capacity of adsorption of the biocomposites $\left(\mathrm{mg} \mathrm{g}^{-1}\right)$ and $\mathrm{n}$ is a measure of the deviation of the model from linearity of the adsorption.

Freundlich model for SEP1, SEP2 and SEP5 was given in Figure 2. The $R^{2}, K_{f}$, relative adsorption capacity and $\mathrm{n}_{\mathrm{f}}$, adsorption intensity are given in Table 4. From Table 4, it is seen that the values of $n_{f}$ are smaller than 1 , reflecting a favorable adsorption. That the adsorption is favorable is also deduced from dimensionless separation factors of Langmuir isotherm [21].

As can be seen from Table 3 and 4, Langmuir adsorption isotherm gave a better fit than Freundlich model based on the correlation coefficients $\left(R^{2}\right)$ value. 
A. Altinisik Tağaç vd. / Adsorption of Remazol Blue (RB) onto The Chitosan/SEP Biocomposite From Aqueous Solution
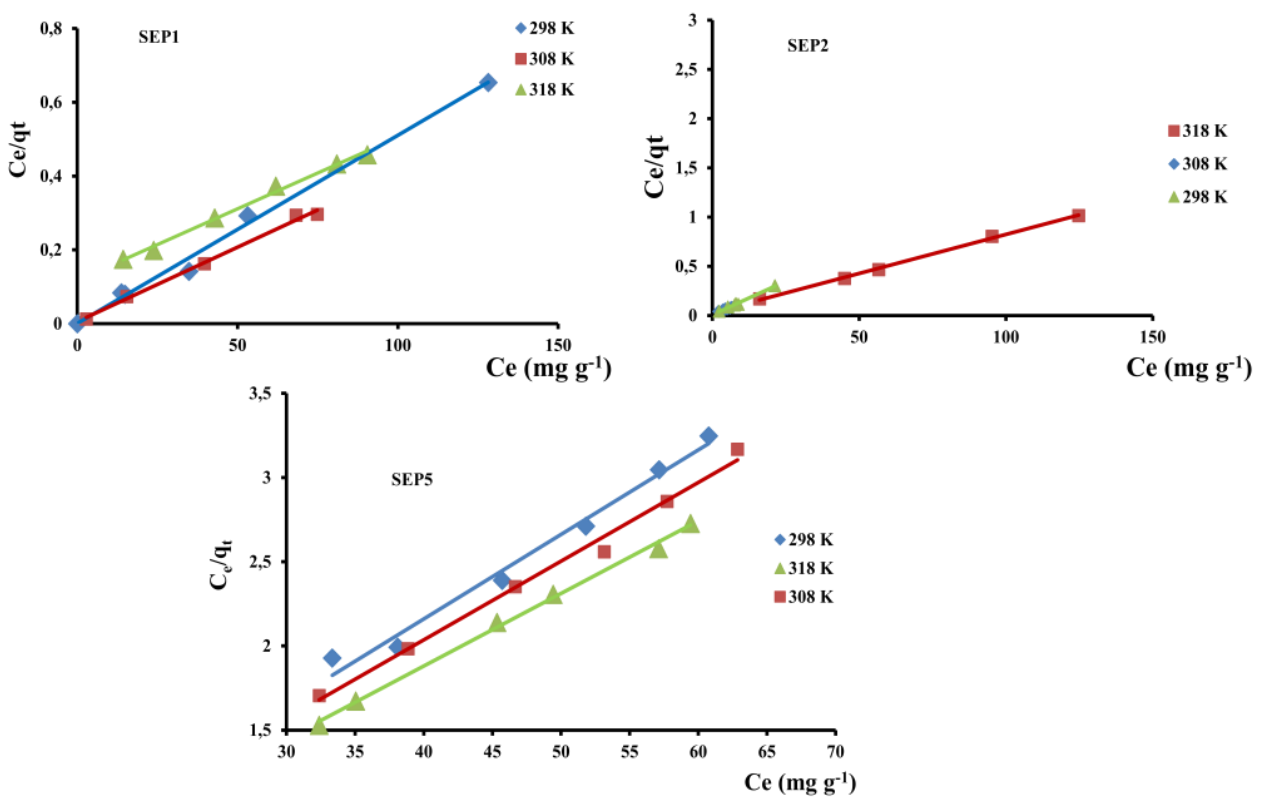

Figure 2. Langmuir isotherms for adsorption of RB onto SEP1, SEP2 and SEP5 at $298 \mathrm{~K}, 308 \mathrm{~K}$ and $318 \mathrm{~K}$

Table 3. The adsorption of Langmuir equation for RB onto SEP1, SEP2 and SEP5 at different temperatures

\begin{tabular}{lllll}
\hline $\mathbf{2 9 8 K}$ & $\mathbf{R}^{\mathbf{2}}$ & $\mathbf{q} \mathbf{m}\left(\mathbf{m g ~ g}^{-\mathbf{1}}\right)$ & $\mathbf{L}\left(\mathbf{L} \mathbf{~ m} \mathbf{g}^{-\mathbf{1}}\right)$ & $\mathbf{R}_{\mathbf{L}}$ \\
\hline SEP1 & 0.99 & 196 & 12.75 & 0.0002 \\
SEP2 & 0.99 & 74 & 1.58 & 0.0080 \\
SEP5 & 0.98 & 20 & 0.30 & 0.0400 \\
\hline 308K & & & & \\
\hline SEP1 & 0.99 & 250 & 0.69 & 0.0050 \\
SEP2 & 0.99 & 116 & 0.35 & 0.0350 \\
SEP5 & 0.99 & 21 & 0.28 & 0.0420 \\
\hline 318K & & & & 0.009 \\
\hline SEP1 & 0.9943 & 256 & 0.03 & 0.015 \\
SEP2 & 0.9973 & 126 & 0.25 & 0.044 \\
SEP5 & 0.997 & 23 & 0.27 & \\
\hline
\end{tabular}


A. Altinisik Tağaç vd. / Adsorption of Remazol Blue (RB) onto The Chitosan/SEP Biocomposite From Aqueous Solution

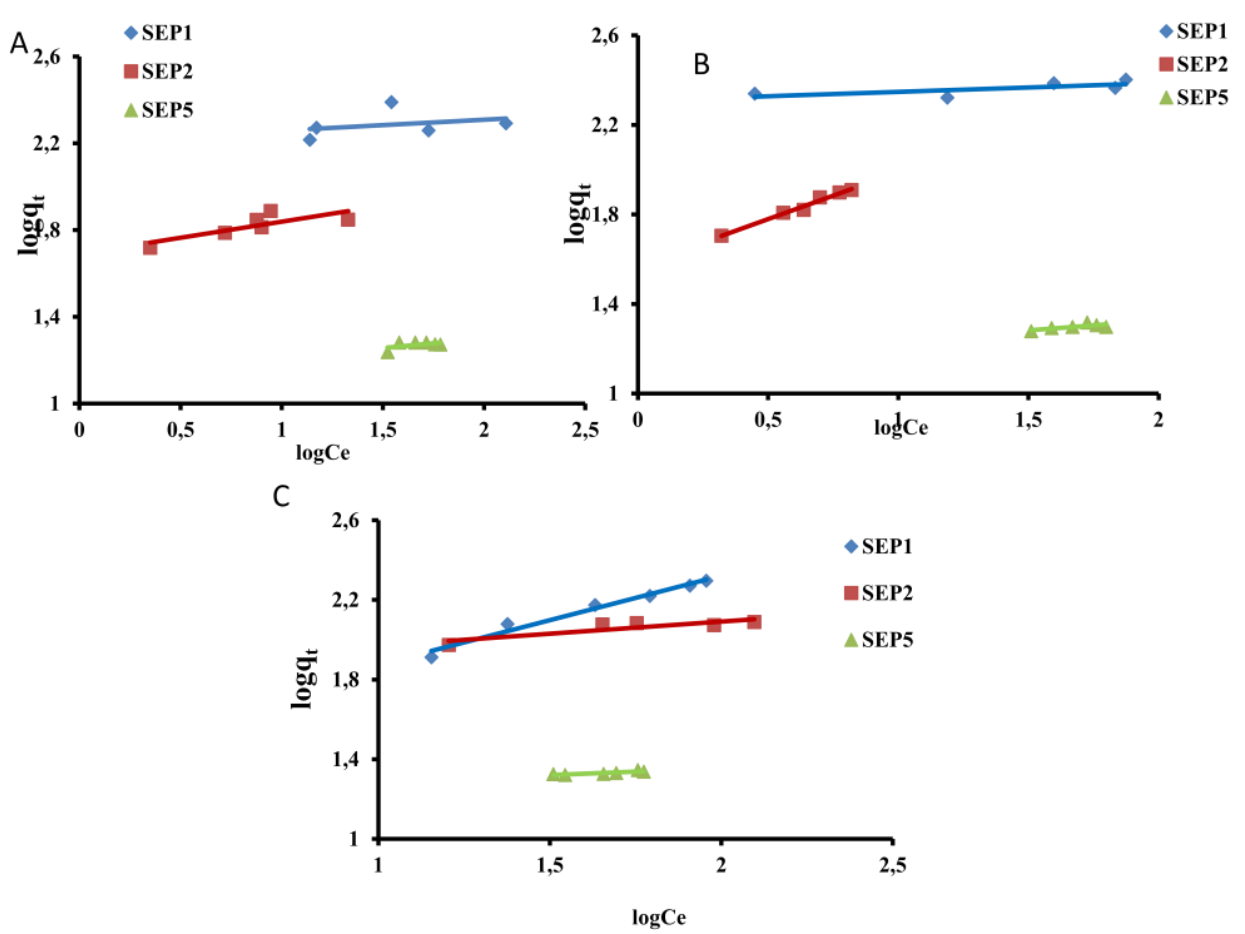

Figure 3. Freundlich isotherms for adsorption of RB onto SEP1, SEP2 and SEP5 at 298K (A), $308 \mathrm{~K}(\mathrm{~B}), 318 \mathrm{~K}(\mathrm{C})$.

Table 4. The adsorption of Freundlich equation for RB onto SEP1, SEP2 and SEP5 at different temperatures

\begin{tabular}{llll}
\hline $\mathbf{2 9 8 K}$ & $\mathbf{R}^{2}$ & $\mathbf{K}_{\mathbf{f}}(\mathbf{m g} \mathbf{g})$ & $\mathbf{n}_{\mathbf{f}}$ \\
\hline SEP1 & 0.09 & 162.3 & 0.0492 \\
$\mathbf{S E P 2}$ & 0.64 & 49.07 & 0.1484 \\
$\mathbf{S E P 5}$ & 0.01 & 12.65 & 0.0222 \\
\hline $\mathbf{3 0 8 K}$ & & & \\
\hline SEP1 & 0.50 & 203.30 & 0.0394 \\
SEP2 & 0.98 & 37.17 & 0.4192 \\
SEP5 & 0.55 & 14.12 & 0.0883 \\
\hline $\mathbf{3 1 8 K}$ & & & \\
\hline SEP1 & 0.97 & 26.78 & 0.4468 \\
SEP2 & 0.77 & 70.11 & 0.1229 \\
SEP5 & 0.72 & 16.44 & 0.0697 \\
\hline
\end{tabular}


3.3. Thermodynamics of Adsorption Thermodynamic parameters such as Gibbs free energy change $\left(\Delta G^{\circ}\right)$, enthalpy change $\left(\Delta \mathrm{H}^{\circ}\right)$ and entropy change $\left(\Delta S^{\circ}\right)$ were estimated for RB adsorption onto SEP1, SEP2 and SEP5. $\Delta G^{\circ}$ values at different temperatures were calculated from the following equation;

$\Delta \mathrm{G}^{\circ}=-\mathrm{RT} \ln (1000 \mathrm{Kd})$

where $\mathrm{Kd}$ is the equilibrium constant at temperature $\mathrm{T}$; $\mathrm{R}$, gas constant (8.314 Jmol-1K-1), and $\mathrm{T}$, absolute temperature $(\mathrm{K})$.

For each temperature, the same $\mathrm{t}$ values selected as $1440 \mathrm{~min}$ and from this value, firstly qt and then qe and $\mathrm{C}_{\mathrm{e}}$ values were calculated by using pseudo-first-order equation. $\mathrm{K}_{\mathrm{d}}$ was estimated using the following equation;

"K $\mathrm{K}_{\mathrm{d}}=$ " "qe" /"Ce"

where $\mathrm{C}_{\mathrm{e}}$ is the equilibrium concentration (mg L-1), qe the amount of adsorbed (mg g-1).

To determine the values of $\Delta \mathrm{H}^{\circ}$ and $\Delta \mathrm{S}^{\circ}$, the van't Hoff equation is used;

$\ln K_{d}=\left(\Delta S^{\circ} / R\right)-\left(\Delta H^{\circ} / R T\right)$

$\Delta \mathrm{S}^{\circ}$ and $\Delta \mathrm{H}^{\circ}$ values can be calculated from the plot of $K_{d}$ versus $1 / T$ as intercept and slope of the line.
Thermodynamic parameters calculated with the first-order rate constant are presented in Table 4.

In order to obtain activation energy of sorption process, Arrhenius equation was used in the following form;

$\operatorname{lnk} 2=\ln \mathrm{A}-\mathrm{Ea} / \mathrm{RT}$

where Ea is the activation energy of sorption, k2, pseudo-second-order rate constant, A, Arrhenius constant, $R$, the gas constant $\left(8.314 \mathrm{Jmol}^{-1} \mathrm{~K}^{-1}\right)$ and $\mathrm{T}$ is the solution temperature $(\mathrm{K})$. The Ea value is obtained from the slope of Arrhenius plot of $\operatorname{lnk} 1$ against 1 /T. The importance of activation energy (Ea) is that it is used to determine the type of adsorption (physical or chemical). The physisorption usually has energies in the range of $0-40 \mathrm{~kJ} \mathrm{~mol}-1$, while higher activation energies $(40-800 \mathrm{~kJ}$ mol-1) suggest chemisorptions [22]. Ea values (higher than $40 \mathrm{~kJ}$ mol-1) shows that chemical adsorption occurs in adsorption process. The absolute magnitude of $\Delta \mathrm{G}^{\circ}$ may give an idea about the type of adsorption. Chemisorption has an energy range 80-400 kJ per unit mole, physical sorption has a range 0 to $-20 \mathrm{~kJ}$ per unit mole [23]. Since $\Delta G^{\circ}$ values obtained in this study are in the range 0 to $-20 \mathrm{~kJ}$ mol-1, sorption of RB onto SEP can be considered as physisorption process. 
A. Altinisik Tağaç vd. / Adsorption of Remazol Blue (RB) onto The Chitosan/SEP Biocomposite From Aqueous Solution

Table 5. Thermodynamic parameters for adsorption of RB onto SEP1, SEP2 and SEP5 at different temperatures

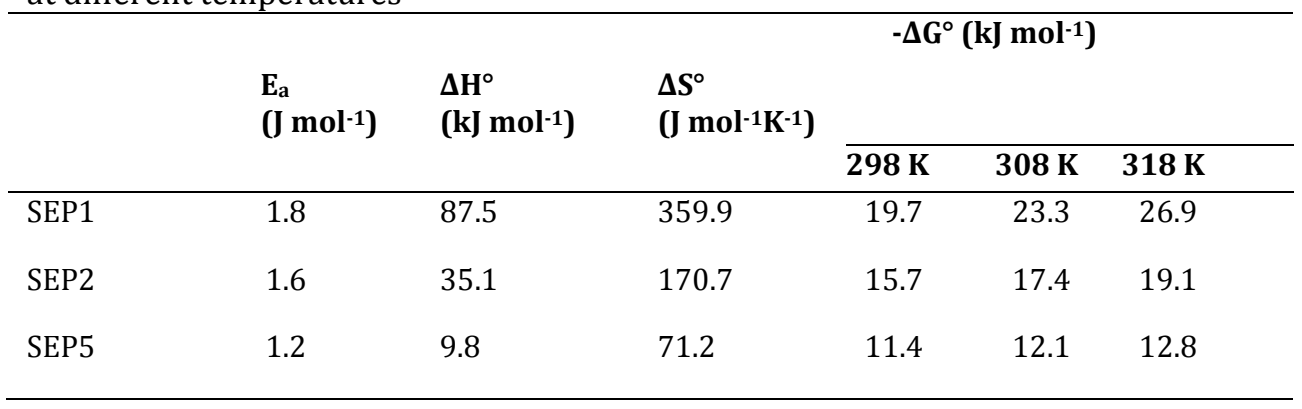
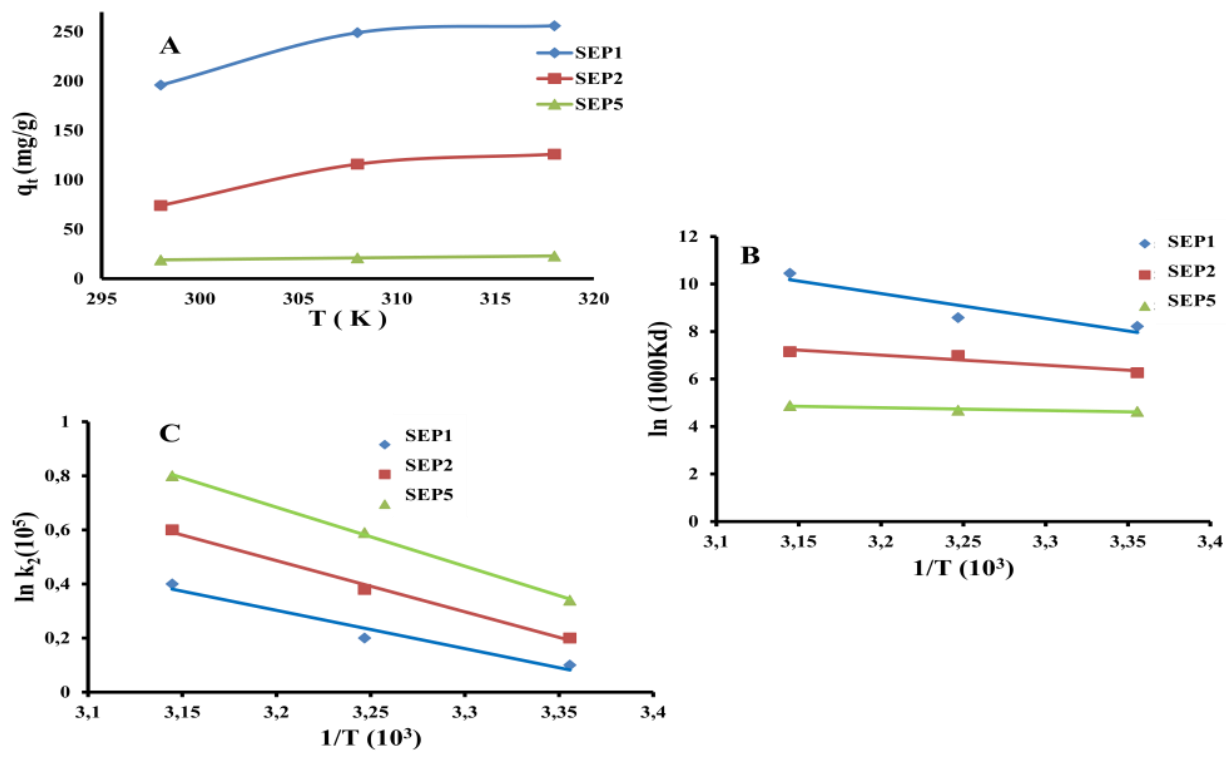

Figure 4. Effect of temperature on RB adsorption (A), Thermodynamic parameters for the adsorption of RB onto biocomposites (B), Thermodynamic parameters calculated from the second-order rate (C). 


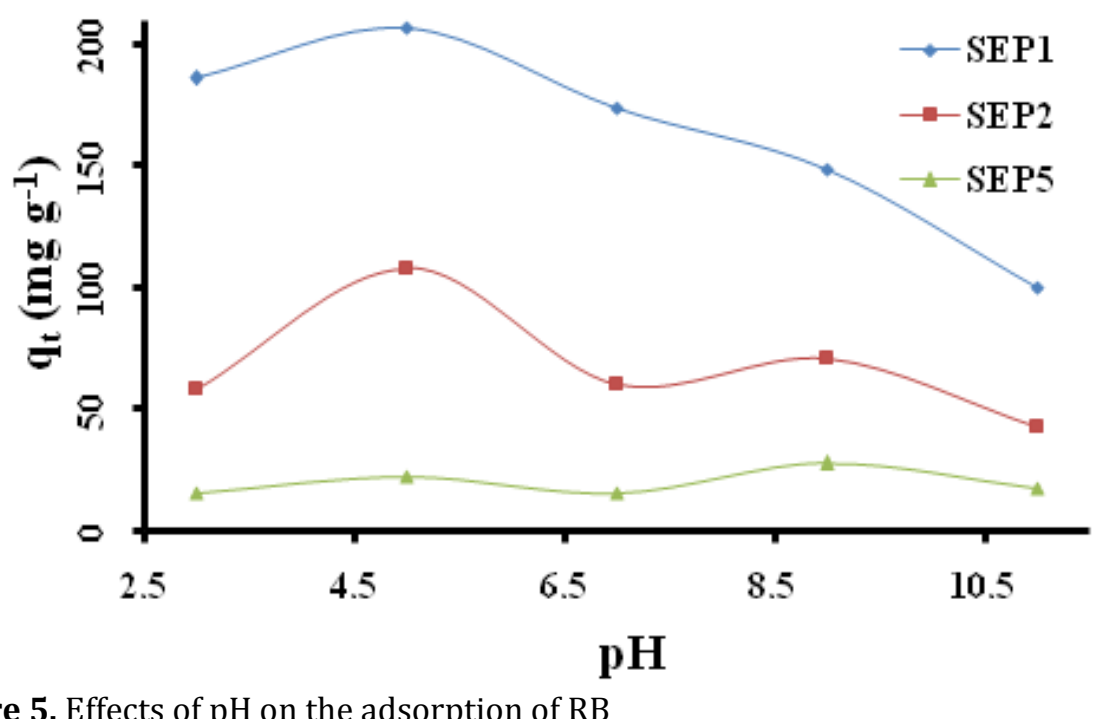

Figure 5. Effects of $\mathrm{pH}$ on the adsorption of RB

\subsection{Effect of $\mathbf{p H}$ on Adsorption of RB onto CS/SEP}

In order to investigate the effect of $\mathrm{pH}$ on adsorption, the studies were performed at different $\mathrm{pH}$ values $\mathrm{(pH} 3$, $5,7,9$ and 11) at a constant temperature of $298 \mathrm{~K}$. In the experiments, adsorbent dosage was selected as $0.02 \mathrm{~g}$. Polyethylene vessels were filled with $25 \mathrm{mLs}$ of dye solutions of $200 \mathrm{ppm}$ concentration. The solutions were shaken at $100 \mathrm{rpm}$ in a temperature controlling shaker for 24 hours. Equilibrium dye concentrations were measured spectrophotometrically at $602.0 \mathrm{~nm}$ by using UV-Visible spectrophotometer.

The results were presented in Figure 5. It is obvious that maximum adsorption at equilibrium was provided at $\mathrm{pH}=5$.

\section{Conclusion}

The adsorption of dye from an aqueous solution onto CS/SEP sepiolite has been investigated under different conditions. The fit of the Langmuir model in the present system shows the formation of a monolayer coverage on the surface of the adsorbent. The Freundlich model was also used to analyze the adsorption data. The adsorption capacities were determined reasonably high at molar ratio CS to SEP 2:1, at $298 \mathrm{~K}$ and $\mathrm{pH}=5$ for adsorption of RB (reactive dye) respectively. The values of dimensionless equilibrium parameters like the separation factor $\left(R_{L}\right)$ (for different SEP1, SEP2 and SEP5) indicates the favorability of the process described in the present study. The kinetics of adsorption of RB followed the pseudo-second-order rate expression. The Langmuir and Freundlich models can be used to describe the dye sorption onto CS/SEP. However, better fit on Langmuir model was observed in the evaluation of the adsorption and the kinetic data.

As the $\mathrm{pH}$ of the system increases, the number of negatively charge sites increased. A negatively charged surface site on the adsorbent favors the adsorption of dye due to the electrostatic repulsion.

As shown in the reported data should be useful for the design and fabrication of an economically viable treatment process using bath (or) stirred tank reactors for dye adsorption and for diluting industrial effluents. 


\section{References}

[1] Reisch, M. S. 1996. Asian textile dye makers are a growing power in changing market. Chemical \& Engineering News, 74(3): 10-12. https://books.google.com.tr/books ?hl=tr\&lr=\&id=bCElDwAAQBAJ\&oi =fnd \&pg=PP1\&dq=\%5B1\%5D $\% 09$ Reisch,+M.+S.+1996.+Asian+textile + dye + makers + are $+\mathrm{a}+$ growing + po wer+in+changing+market. + Chemic al+\%26+Engineering+News, $+74(3)$ $\pm+10-$

$\underline{12 .+ \text { \&ots }=0 \text { NSB } 5 \times \text { PqvU\&sig }=0 P 1 c}$ 3f9je DaPgYXAa4joms6tWA\&redir esc $=\mathrm{y} \# \mathrm{v}=$ onepage $\& \mathrm{q} \& \mathrm{f}=$ false

[2] Robinson, T., McMullan, G., Marchant, R., \& Nigam, P. 2001. Remediation of dyes in textile effluent: a critical review on current treatment technologies with a proposed alternative. Bioresource technology, 77(3): 247-255. https://doi.org/10.1016/S09608524(00)00080-8

[3] Georgiou, D., Melidis, P., Aivasidis, A., \& Gimouhopoulos, K. 2002. Degradation of azo-reactive dyes by ultraviolet radiation in the presence of hydrogen peroxide. Dyes and pigments, 52(2): 69-78. https://doi.org/10.1016/S01437208(01)00078-X

[4] Al-Degs, Y., Khraisheh, M. A. M., Allen, S. J., \& Ahmad, M. N. 2000. Effect of carbon surface chemistry on the removal of reactive dyes from textile effluent. Water Research, 34(3): 927-935. https://doi.org/10.1016/S00431354(99)00200-6

[5] Gupta, G. S., Prasad, G., \& Singh, V. N. 1990. Removal of chrome dye from aqueous solutions by mixed adsorbents: fly ash and coal. Water Research, 24(1): 45-50. https://doi.org/10.1016/00431354(90)90063-C
[6] Lambert, S. D., Graham, N. J. D., Sollars, C. J., \& Fowler, G. D. 1997. Evaluation of inorganic adsorbents for the removal of problematic textile dyes and pesticides. Water science and technology, 36(2-3): 173-180.

https://doi.org/10.1016/S02731223(97)00385-5

[7] Gür, E., Altinisik, A., \& Yurdakoc, K. 2015. Preparation and characterization of chitosan/sepiolite

bionanocomposites for tetracycline release. Polymer Composites. http://onlinelibrary.wiley.com/doi 110.1002/pc.23751/pdf

[8] Low, K. S., \& Lee, C. K. 1997. Quaternized rice husk as sorbent for reactive dyes. Bioresource Technology, 61(2): 121-125. https://doi.org/10.1016/S09608524(97)00054-0

[9] Morais, L. C., Freitas, O. M., Goncalves, E. P., Vasconcelos, L. T., \& Beca, C. G. 1999. Reactive dyes removal from wastewaters by adsorption on eucalyptus bark: variables that define the process. Water Research, 33(4): 979-988. https://doi.org/10.1016/S00431354(98)00294-2

[10] Łebek, J., \& Wardas, W. 1996. Adsorption of some textile dyes on post-vanillin lignin during its precipitation. Cellulose chemistry and technology, 30(3-4): 213-221. http://cat.inist.fr/?aModele=affich eN\&cpsidt $=2549246$

[11] Mckay, G., Blair, H. S., \& Gardner, J. 1983. The adsorption of dyes in chitin. III. Intraparticle diffusion processes. Journal of Applied Polymer Science, 28(5): 1767 1778.

http://onlinelibrary.wiley.com/doi /10.1002/app.1983.070280519/fu $\underline{11}$

[12] Kumar, M. N. R. 2000. A review of chitin and chitosan 
applications. Reactive and functional polymers, 46(1): 1-27. https://doi.org/10.1016/S13815148(00)00038-9

[13] Wang, S. F., Shen, L., Tong, Y. J., Chen, L., Phang, I. Y., Lim, P. Q., \& Liu, T. X. 2005. Biopolymer chitosan/montmorillonite nanocomposites: preparation and characterization. Polymer Degradation and Stability, 90(1): 123-131.

http://www.sciencedirect.com/sci ence/article/pii/S0141391005001 $\underline{321}$

[14] Giles, C. H., \& Hassan, A. S. A. 1958. Adsorption at organic surfaces Va study of the adsorption of dyes and other organic solutes by cellulose and chitin. Coloration Technology, 74(12): 846-857. http://onlinelibrary.wiley.com/doi /10.1111/i.14784408.1958.tb02236.x/full

[15] Bousher, A., Shen, X., \& Edyvean, R. G. 1997. Removal of coloured organic matter by adsorption onto low-cost waste materials. Water Research, 31(8): 2084-2092. https://doi.org/10.1016/S00431354(97)00037-7

[16] Allen, S. J., \& Koumanova, B. 2005. Decolourisation water/wastewater using adsorption. Journal of the University of Chemical Technology and Metallurgy, 40(3): 175-192. http://dl.uctm.edu/journal/node/i 2005-3/Revew.pdf

[17] Brauner K. \& Preisinger A. 1956 Struktur und Entstehungdes sepioliths. Tschhermarks Min. Pert. Mitt. 6, 120-140. https://link.springer.com/article/ $\underline{10.1007 \% 2 F B F 01128033 ? \mathrm{LI}=\text { true }}$

[18] Habish, A. J. 2017. Uticaj parametara sinteze na svojstva kompozitnih adsorbenata na bazi sepiolita i nanočestica elementarnog gvožđa (Influence of synthesis parameters on the properties of the composite adsorbents based on sepiolite and nano-zerovalent iron) (Doctoral dissertation, Univerzitet $\mathrm{u}$ Beogradu-Tehnološko-metalurški fakultet). Lagaly, G. 1999. Introduction: from clay mineralpolymer interactions to clay mineral-polymer nanocomposites. Applied Clay Science, 15(1): 1-9. http://uvidok.rcub.bg.ac.rs/bitstre am/handle/123456789/1831/Dok torat.pdf? sequence $=1$

[19] Cengiz, S., Çavaş, L., \& Yurdakoç, K. 2012. Bentonite and sepiolite as supporting media: Immobilization of catalase, Applied Clay Science, 65: 114-120. http://www.sciencedirect.com/sci ence/article/pii/S0169131712001 $\underline{639}$

[20] Poots, V. J. P., Mckay, G., \& Healy, J. J. 1976. The removal of acid dye from effluent using natural adsorbents-II wood. Water Research, 10(12): 1067-1070. http://www.sciencedirect.com/sci ence/article/pii/00431354769003 $\underline{73}$

[21] Nollet, H., Roels, M., Lutgen, P., Van der Meeren, P., \& Verstraete, W. 2003). Removal of PCBs from wastewater using fly ash. Chemosphere, 53(6), 655-665. http://www.sciencedirect.com/sci ence/article/pii/S0045653503005 $\underline{174}$

[22] Altınışık, A., Gür, E., \& Seki, Y. (2010). A natural sorbent, Luffa cylindrica for the removal of a model basic dye. Journal of Hazardous Materials, 179(1): 658664.

https://doi.org/10.1016/j.jhazmat. $\underline{2010.03 .053}$ 